\title{
Lexicographic Treatment of Zero Equivalence in isiZulu Dictionaries
}

\author{
D.J. Prinsloo, Department of African Languages, University of Pretoria, \\ Pretoria, South Africa (danie.prinsloo@up.ac.za) \\ and \\ Nompumelelo Zondi, Department of African Languages, University of \\ Pretoria, Pretoria, South Africa (mpume.zondi@up.ac.za)
}

\begin{abstract}
One of the main tasks of compilers of bilingual dictionaries is to find suitable translation equivalents for source language lemmas in the target language. It could be expected that to a large degree one should find full equivalence, or at least partial equivalents in the target language and that there might not be many instances where such translation equivalents are not available. Typically common words such as table, chair, man, woman come to mind and they are most likely to have equivalents in the target language. This article focuses on lexical and referential gaps between English and isiZulu, and their treatment in English and isiZulu paper dictionaries. The aim is to determine to what extent suitable translation equivalents are available for English and isiZulu lemmas and what the nature, extent and treatment strategies are in cases where such equivalents are not available. It will be shown that the extent of zero equivalence is much higher for this language pair than expected in general literature on zero equivalents. In some cases a specific concept is known in the target language but the target language has no word for it but in many instances the concept itself is unknown in the target language which implies that the language will also not have a word for such a concept.
\end{abstract}

Keywords: LEXICOGRAPHY, BILINGUAL DICTIONARIES, EQUIVALENCE, TRANSLATION EQUIVALENTS, ZERO EQUIVALENCE, LEXICAL GAPS, REFERENTIAL GAPS, ISIZULU, PARAPHRASE OF MEANING, SURROGATE EQUIVALENTS

Opsomming: Leksikografiese bewerking van zero-ekwivalensie in isiZulu woordeboeke. Een van die hooftake van samestellers van tweetalige woordeboeke is om geskikte vertaalekwivalente vir brontaal-lemmas in die doeltaal te vind. Daar kan verwag word dat 'n mens in 'n groot mate volle ekwivalensie of ten minste gedeeltelike ekwivalente in die doeltaal sal vind, en dat daar moontlik nie baie gevalle sal wees waar sulke vertaalekwivalente nie beskikbaar is nie. Gewoonlik word eerste gedink aan gewone woorde soos tafel, stoel, man, vrou en is dit waarskynlik dat hulle ekwivalente in die doeltaal sal hê. Hierdie artikel fokus op leksikale en verwysingsgapings tussen Engels en isiZulu en hulle bewerking in papierwoordeboeke vir Engels en isiZulu. Die doel is om vas te stel tot watter mate geskikte vertaalekwivalente beskikbaar is vir Engelse en isiZulu lemmas en wat die aard, omvang en behandelingstrategieë is in gevalle waar sulke ekwivalente nie beskikbaar is nie. Daar sal aangetoon word dat die omvang van zero-ekwiva- 
lensie vir hierdie taalpaar veel groter is as wat in die algemene literatuur verwag word oor zeroekwivalente vir beide leksikale en verwysingsgapings. In sommige gevalle is ' $n$ spesifieke begrip in die doeltaal bekend, maar die doeltaal het geen woord daarvoor nie, maar in baie gevalle is die begrip self onbekend in die doeltaal, wat impliseer dat die taal ook nie 'n woord vir so 'n begrip sal hê nie.

Sleutelwoorde: LEKSIKOGRAFIE, TWEETALIGE WOORDEBOEKE, EKWIVALENSIE, VERTAALEKWIVALENTE, ZERO-EKWIVALENSIE, LEKSIKALE GAPINGS, REFERENSIËLE GAPINGS, ISIZULU, BETEKENISOMSKRYWING, SURROGAATEKWIVALENTE

\section{Introduction}

In an ideal world suitable translation equivalents for each lemma in a bilingual dictionary should be available in the target language. The prospective compiler of a bilingual dictionary might assume that one can expect to find translation equivalents for all lemmas and that there might not be many instances where such translation equivalents are not available. Taken at face value, considering common objects and concepts, a first impression is that both the source and target languages have suitable translation equivalents. Such an assumption could be strengthened by Adamska-Sałaciak's (2006: 117) view that "zero equivalence, while more frequent, is also relatively rare". Gouws and Prinsloo (2008: 869), however, state that there are frequent instances in any given language pair where suitable translation equivalents are not available. It also has to be kept in mind that English is a language with a deeply rooted lexicographic tradition and isiZulu, although having excellent dictionaries, is a language with a strong oral tradition, rich in cultural terminology. Adamska-Sałaciak (2006: 24) says that "bilingual dictionaries have to try and do their job despite the fact that the lexicons of natural languages are resistant to pairwise matching" and that finding suitable translation equivalents is problematic because a precise one-toone correlation between a word and a translation equivalent is rare. AdamskaSałaciak (2006: 99) goes as far as to state that "due to interlingual anisomorphism a bilingual dictionary is, strictly speaking, an impossibility" and that "all we can hope to produce are better or worse approximations".

The aim of this article is to determine for the language pair isiZulu and English to what extent suitable translation equivalents are available for English and isiZulu lemmas and what the nature, extent and treatment strategies are in cases where translation equivalents are not available.

\section{Equivalence in bilingual dictionaries}

The core of the task of the bilingual lexicographer is to find translation equivalents in the target language for lemmas in the source language. Gouws and Prinsloo (2005: 158) state that the lexicon of a language "does not necessarily 
develop parallel to the lexicon of any other language". They emphasize that when a language acquires a word for a given concept it does not imply that other languages will do the same. The views of Gouws and Prinsloo (2005) and Adamska-Sałaciak (2006) are in line with Dagut's (1981) view that equivalence between languages are in principle characterized by a degree of incompatibility and the difficulty, if not impossibility to find translation equivalents in all cases.

... translation is viewed as an attempt to achieve a relationship of "equivalence" between two languages (the SL and the TL), an attempt which, by its very nature, focuses attention on all those incommensurabilities of the two languages concerned that render such "equivalence" difficult (if indeed possible) of attainment. ... The as yet undefined key-term, "equivalence," is to be understood in the Saussurean sense of equal linguistic "value," i.e., as the relationship existing between an item in SL and one in TL, when the TL item performs as nearly as possible the same semantic function in TL as the SL item in SL. (Dagut 1981: 61)

Ideal for the bilingual lexicographer are instances of full equivalence, also known as congruence where, in terms of Gouws and Prinsloo (2005: 154) "the source language item and the target language item have exactly the same meaning, function on the same stylistic level and represent the same register". This means that there are no restrictions on the use of the translation equivalent as in example (1).

(1)

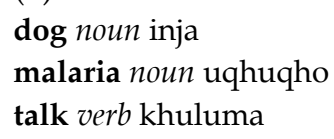

Gouws and Prinsloo (2008 and 2010) emphasize that in most cases, however, a relation of full equivalence does not exist. Gouws and Prinsloo (2008: 870) state "when comparing any two languages one soon becomes aware of the absence of certain words in a given language". They emphasize that "even highly used common words in a language could lack suitable translation equivalents in the target language". In the absence of full equivalence, the lexicographer tries to find partial equivalents as illustrated in example (2).

(2)

incasiso noun solution

In (2) the English word solution is a partial equivalent of incasiso only in the context of an explanation. Solution also has other senses e.g. liquid.

If it is not possible for the lexicographers to find translation equivalents, they are compelled to revert to surrogate equivalents to make up for the lack of full or partial equivalents. These are instances where lexical gaps exist between 
source and target language. The absence of suitable translation equivalents is referred to as zero equivalence

The Dictionary of Lexicography $(D L)$ does not offer treatment of the lemma surrogate equivalent but gives a cross-reference to explanatory equivalent and defines it as in figure 1 .

\section{explanatory equivalent \\ In the translation of CULTURE-SPECIFIC VOCABU- LARY, the explanation of a word or phrase by means of a surrogate PARAPHRASE in the target language rather than a one-to-one EQUTVALENT, e.g. German Dolchstoßlegende - English 'myth of the "stab in the back" (betrayal of Germany after the First World War by its own politicians)'. C. Zgusta 1984, Schnorr 1986.}

Figure 1: Explanatory equivalent in Dictionary of Lexicography

Dagut (1981: 64) distinguishes two types of lexical gaps namely (a) linguistic gaps resulting from linguistic factors and (b) referential gaps caused by linguistic-external factors. A linguistic gap occurs when the concept is known in both the source and target languages but the target language does not have a specific word for it. A referential gap occurs when a source language concept is unknown in the target language.

The strategies employed in the case of zero equivalence include the use of glosses, paraphrase of meaning, pictures and illustrations and information boxes. Consider table 1 and examples (3) and (4) from the English-isiZulu Dictionary (henceforth referred to as EID), Scholar's Zulu Dictionary (SZD) and Compact Zulu Dictionary (CZD)

Table 1: $\quad$-ngcuba in EID, SZD and CZD

\begin{tabular}{|l|l|l|}
\hline EID & SZD & $C Z D$ \\
\hline $\begin{array}{l}\text {-ngcuba (ingcuba, 2.9.9, izingcuba) n. } \\
\text { 1. Meat of an animal that has died, } \\
\text { not been slaughtered. }\end{array}$ & $\begin{array}{c}\text {-ngcuba (i-) (n) meat of an } \\
\text { animal which has died } \\
\text { from natural causes. }\end{array}$ & $\begin{array}{c}\text {-ngcuba (n) (ingcuba, izingcuba), } \\
\text { meat of an animal which has } \\
\text { died from natural causes. } \\
\text { 2. Lean meat. }\end{array}$ \\
& & \\
\hline
\end{tabular}


(3)

mistral ['mistral] $n$. uhlobo lomoya oyisiphepho obandayo.

In table 1 there is no English translation equivalent for the isiZulu word ingcuba. In this case paraphrase of meaning and two short descriptions are given. Table 1 reflects zero equivalence in the form of a lexical gap, i.e. the concepts meat of an animal which died from natural causes, lean meat and worthless person are known to speakers of English but there are no English translation equivalents. Likewise, in (3) there is no isiZulu translation equivalent for the English word mistral. In such cases the challenge for the lexicographer is to treat the lemma mistral in such a way that users get the required information from the dictionary. The Collins Dictionary gives the meaning of mistral as 'a strong, cold north-westerly wind that blows through the Rhône valley and southern France into the Mediterranean, mainly in winter' (https://www. collinsdictionary.com/dictionary/english/mistral). The entire concept of a wind blowing through the Rhône valley and southern France into the Mediterranean is unknown in isiZulu, thus representing a referential gap in addition to the language not having a word for it. Thus in terms of Dagut (1981: 63) "there is no single designator ... which provides the required equivalent encapsulation" in isiZulu of "strong, cold north-westerly wind" + "Rhône valley" + "southern France" + "into the Mediterranean". It is not a matter of an inability in the target language to express the meaning of the source language item but whether equivalents are available in the target language.

The question under investigation here is not whether anything said in language A can also be said, in some way, in language B, but rather what happens (in terms of translation equivalence) when $\mathrm{A}$ is lexically better equipped than $\mathrm{B}$ to say a certain thing. And "better equipped" refers to A's possession of the compressed power of a designator which B lacks. (Dagut 1981: 64)

In (3) the lexicographer opted to give a paraphrase of meaning using a possessive construction uhlobo lomoya. 'type of wind', and verbal relative oyisiphepho obandayo 'a strong cold wind' (a strong wind which is cold). This is still a far cry from a description of all the meaning connotations of mistral conveyed in the Collins Dictionary entry but at least captures the core semantic elements.

The concept hlonipha is unknown in English. English therefore lacks a translation equivalent. This means that the lexicographer first has to introduce the concept to the users and then find a way to tell them what it means and not surprisingly leads to lengthier articles, cf. the article for hlonipha in figure 2. 


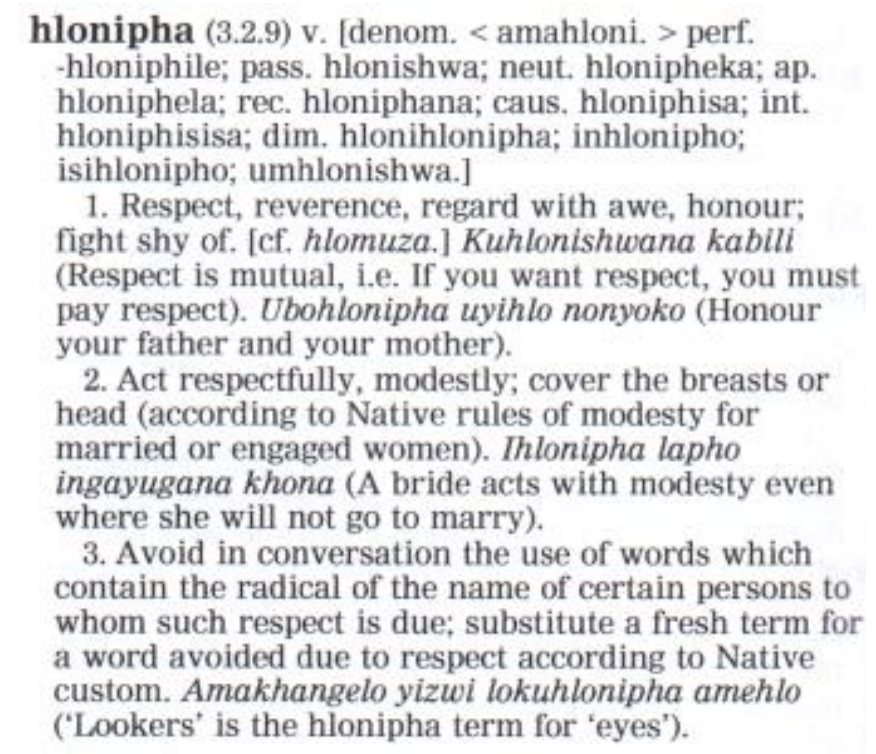

Figure 2: Article for hlonipha in EID

Consider also cultural words such as isidanga 'a kind of necklace', umhlaba 'red arrow' and $u k h u z o$ 'customary ceremony' where the treatment in the central text by The Greater Dictionary of (isi)Xhosa volumes 1, 2 and 3 (GDX1, GDX2 and GDX3) is supplemented by lengthy addenda in the back matter of the dictionaries. As far as necklace is concerned, dictionaries such as the English Xhosa Dictionary (EXD) and Xhosa Live Dictionary (https://www.gononda.com/xhosa/) give a surrogate equivalent intsimbi yomqala 'iron of the neck' or a loan word ineklesi 'necklace' respectively.

(4)

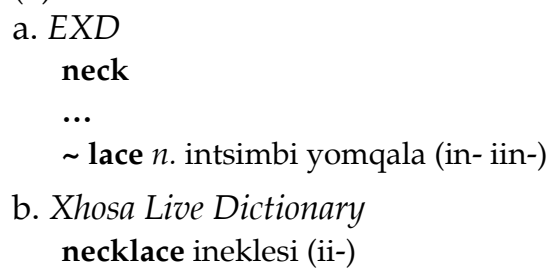

GXD1, however, gives a detailed treatment for isidanga in figure 3 in the central text of the dictionary supplemented by more detailed information given in the form of an addendum (12) in isiXhosa, English and Afrikaans in the back matter as given in figure 4 for isiXhosa and English. 


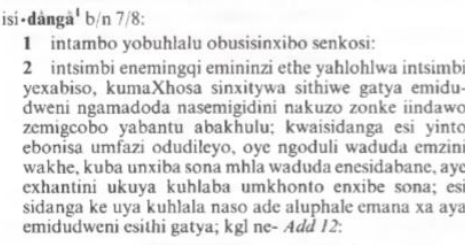

1 traditional royal necklet of red beads: 2 an ornament consisting of many strings of blue beads worn around the neck and proud possession of an adult Xhos, wo by men on all ceremonial occasions, eg a weddings and other festivities; a woman wears hers at her wedding (umdudo, qv) when she thrusts the assegai into the groun at the kraal gate (see uk uhlaha umk honto) thereafter she wears it at all festivities as a proud token or her having been married by koninklike halssnoer van rooi krale 2 ornament van blou krale bestaande uit veelvuldige stringe wat om die nek en trotse besitting van 'n volwasse Xhosa; mans dra dit by alle seremoniele geleenthede soos huwelike en ander feeste; in vrou dra hare op haar huweliksdag (umdudo $\mathrm{q}$ v) wanneer sy die assegaai by die kraalhek in die grond steek (sten

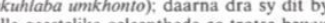
alle geestelike gelecnthede as trotse bewys gehuud is: sien ook Add 12 .

Figure 3: Article for isidanga in GDX1

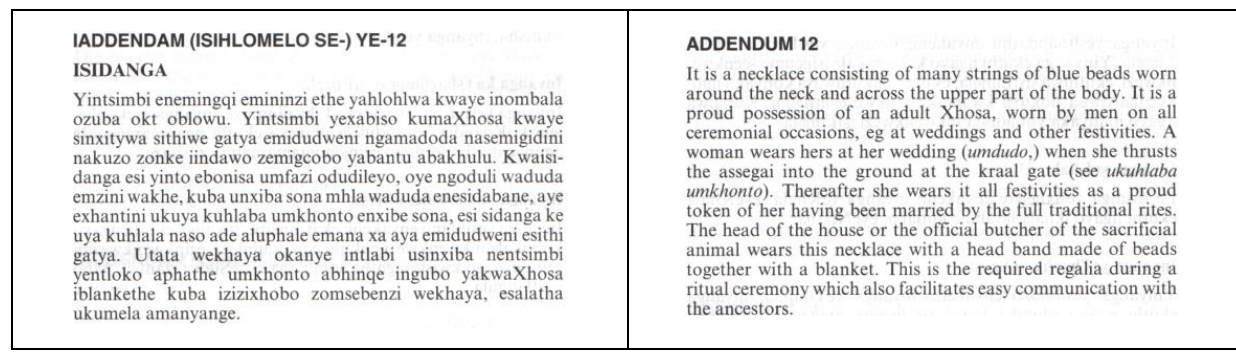

Figure 4: Addendum for isidanga in GDX1

Gouws and Prinsloo (2008: 873) propose a hierarchy of surrogate equivalents where taboo, culture specific or sensitive values represent the top tier. They state that in such cases treatment will go further than short paraphrases of meaning - the lexicographer has to revert to more elaborate descriptions, pictorial illustrations, etc.

As a second example consider a taboo word in isiZulu in example (5).

(5)

Oxford Zulu Dictionary (OZD)

umfana *** noun 1/2 (pl. abafana) a boy

- Umfana wakwamakhelwane usikwe ibhodlela.

The boy from next door was cut by a bottle.

Umfana is a top frequency word in isiZulu, appropriately marked as such by a three star $\left(^{* * *}\right)$ rating in OZD. It is furthermore unmarked, suggesting that it can be used in all contexts to refer to a boy. There is, however, a taboo word umkhapheyana for umfana for which English has a referential gap and which will require a much more detailed treatment and a taboo-alert as in (6). 
(6)

umkhapheyana noun $1 / 2$ ( $p l$. abakhapheyana)

Hlonipha term for umfana boy / abafana boys.

A woman married into polygamy will avoid mentioning/uttering/saying the words umfana/abafana since the husband was also first a boy before being a husband. So it is taboo in this setting to ever utter such a word, be it in the singular or plural

The value of a pictorial illustration as surrogate equivalent is clear in cases where a mere description is insufficient. So, for example, is a Yorkshire terrier described in the Macmillan Dictionary (MD) as a small dog with long shiny pale brown hair, supplemented by a picture. The description given is fine but without a picture, e.g. as in figure 5, the user will still not know how a Yorkshire terrier really looks like in contrast to other small dogs with long brown hair. The isiZulu lexicographer can even coin the term iYorkshire terrier and give it as a translation equivalent for Yorkshire terrier but that won't be of much help to the user. A combination of a definition and a pictorial illustration as in example (7) and figure 5 is much more informative.

(7)

\section{iYorkshire terrier}

Inja encane, eyazalwa ngekhulu le -19 , eYorkshire eNgilandi, ubude bayo buthi abube ngamasentimitha angama-20 futhi ingaphila isikhathi esithi masibe yi-15. Ngokuvamile iba nombala omnyama okuthi ngokukhula kwayo ugquke ube mpunga.

A small dog, bred in the 19th century, Yorkshire England, height approx $20 \mathrm{~cm}$, life expectancy approx 15 years, typical colour black turning to grey colour as it gets older.

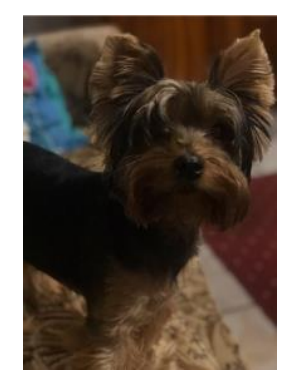

Figure 5: Picture of a typical Yorkshire terrier 
The question to be addressed in the following section is to what extent does the lexicographer in a bidirectional bilingual English-isiZulu dictionary has to deal with zero equivalence. Will it be a matter of finding surrogate equivalents for a few rare cases according to the view of Adamska-Sałaciak or that instances of zero equivalence between English and isiZulu are so frequent that it presents a major challenge to the lexicographer?

\section{Zero equivalence in English-isiZulu dictionaries}

Consider the following analysis of a single, randomly selected page from the English-isiZulu side of EID covering the lemma stretch misdealings to mitigate and a random page from the isiZulu-English side of the same dictionary covering the lemma stretch -ngcuba to -ngeke in the following discussion.

\begin{tabular}{|c|c|}
\hline $\begin{array}{l}\text { nisdealings ['mis'di:linz] } n \text {. izeleleso (4). } \\
\text { nisdeed ['mis'di:d] } n \text {. iseleleso (4), impambuko, } \\
\text { isiphosiso, i(li)cala, isono (4); isenzo esibi. } \\
\text { nisdemeanour ['misdi'mi:na] } n \text {. iseleleso (4); } \\
\text { ukuziphatha kabi. } \\
\text { misdirect ['misdai'rekt] } v . t \text {. qondisa kabi, dukisa; } \\
\text { faka ikheli elingeyilo. } \\
\text { misdirection ['misdi'rek } \\
\text { misdon] } n \text {. ukuquondiswa kabi. } \\
\text { niser ['maiza] } n \text {. umuntu ombanyileyo, unqodoyi (1a), } \\
\text { i(li)qongqela. }\end{array}$ & $\begin{array}{l}\text { catch: ehluleka ukwenqaka; m. out. shiya, sulazela. } \\
\text { (ii) (feel absence of) swela, ntula; They m. him very } \\
\text { much: Bamntula kakhulu. } \\
2 . n \text {. (i) ukugeja, ukuphutha. (ii) *umisi (1a); } \\
\text { inkosazana, intombazana. (iii) Miss: uNkosazana; } \\
\text { Miss Jones: uNkosazana Jones. } \\
\text { missal ['misel] } n \text {. incwadi equkethe inkonzo yemisa. } \\
\text { misshapen ['mis' 'eipen] } a \text {. -bunjiwe kabi, } \\
\text {-magodolozi. } \\
\text { missile ['misil or 'misail] } n \text {. isilabi, umlandeliselo (2); } \\
\text { into ejukujelwayo. }\end{array}$ \\
\hline $\begin{array}{l}\cdots \\
\cdots\end{array}$ & \\
\hline $\begin{array}{l}\text { misread ['mis'ri:d] v.t. funda kabi, -ngafundisisi. } \\
\text { misreport ['misri'ps:t] v.t. bika ngokungeyikho. } \\
\text { misrepresent ['misrepri'zent] v.t. sonta; } \\
\text { phendukezela iqiniso lento; hlanekezela. } \\
\text { misrepresentation ['misreprizen'teifən] } n \text {. } \\
\text { inhlanekezela. } \\
\text { misrule ['mis'ru:l] 1. v.t. phatha kabi, busa kabi. } \\
2 . n \text {. ukuphatha kabi. } \\
\text { miss [mis] 1. v.t. (i) (fail) duka, phutha; } \text { m. the mark: } \\
\text { geja, phaphalaza; } \text { m. the train: shiywa yisitimela; } m \text {. a }\end{array}$ & $\begin{array}{l}\text { misunderstanding ['missnda'stændip] } n \text {. (i) } \\
\text { ukungaqondi kahle; inzwakabi. (ii) ukungezwani, } \\
\text { ukungabonani. } \\
\text { misuse ['mis'ju:s] } n \text {. ukuphatha kabi. } \\
\text { misuse ['mis'ju:z] v.t. sebenzisa ngendlela engalungile. } \\
\text { mite [mait] } n \text {. (i) (insect) ubuvunya, isibungu. (ii) } \\
\text { (childd) umntwanyana omncane. (iii) (coin) } \\
\text { uhlamvanyana lwemali. (iv) (tiny thing) } \\
\text { u(lu)chokwana, u(lu)hoyizana. } \\
\text { mitigate ['mitigeit] v.t. thambisa, nciphisa; } m \text {. } a \\
\text { sentence: nciphisa isigwebo. }\end{array}$ \\
\hline
\end{tabular}

Figure 6: Extracts from the stretch misdealings to mitigate in EID

This page is part of the alphabetical stretch M. Seventy-five lemmas are presented on this page and 74 were treated. For 53 lemmas isiZulu translation equivalents are offered of which 29 lemmas were treated using only translation equivalents. For 45 lemmas surrogate equivalents were given of which 21 lemmas were treated using only surrogate equivalents. Twenty four lemmas were treated using both translation equivalents and surrogate equivalents. What is important to note is the huge number of lemmas for which surrogate equivalents were used in the treatment, i.e. 45 from $74=60,8 \%$, in contrast to translation equivalents 53 out of $74=71.6 \%$ - thus, even though more lemmas were 
treated with translation equivalents, a substantial number of lemmas were treated by surrogate equivalents. Consider table 2 and figure 7 .

Table 2: The use of translation equivalents and surrogate equivalents in the English-isiZulu side of EID

\begin{tabular}{|l|c|c|}
\hline \multicolumn{1}{|c|}{ English-isiZulu } & Counts & $\%$ \\
\hline Lemmas treated with translation equivalents & 53 & 71,6 \\
\hline Lemmas treated with surrogate equivalents & 45 & 60,8 \\
\hline Lemmas treated with translation equivalents only & 29 & 39,2 \\
\hline Lemmas treated with surrogate equivalents only & 21 & 28,4 \\
\hline $\begin{array}{l}\text { Lemmas treated with both translation equivalents and } \\
\text { surrogate equivalents }\end{array}$ & 24 & 32,4 \\
\hline
\end{tabular}

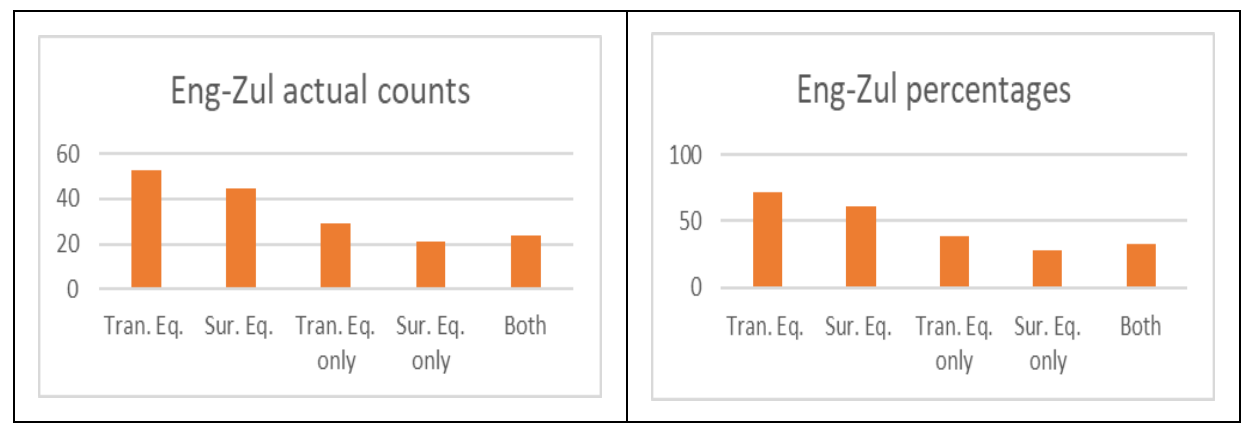

Figure 7: Translation equivalents and surrogate equivalents in -misdealings to -mitigate in EID

In total 194 equivalents were offered for the 74 lemmas treated of which 58 , i.e. $29,9 \%$ were surrogate equivalents. Consider (8)-(10) as examples of treatment.

(8)

Translation equivalents only

misdealings ... $n$. izeleleso ....

misgiving ....n. ukusola, $\mathrm{u}(\mathrm{lu})$ khonono.

misguided ... a. -dukile, -dukisiwe, -khohlisiwe. 
(9)

Surrogate equivalents only

misspell ... v.t. bhala ngokungalungile, pela kabi.

misspend ... v.t. chitha imali.

misprint ... 1. v.t. cindezela isiphosiso.

2. $n$. isiphosiso ekucindezelweni.

(10)

Both translation and surrogate equivalents

misdirect ... v.t. qondisa kabi, dukisa; faka ikheli elingeyilo.

mistress ... n. (i) (woman in authority) *umesisi (la), inkosikazi; umaqumbane (la); school $m .:$ *uthishakazi; singing $m$.: umculisi wesifazane. (ii) (paramour) i(li)shende. (iii) (= Mrs.) uNkosikazi.

mitigate ['mitigeit] $v$.t. thambisa, nciphisa; $m$. a sentence: nciphisa isigwebo.

Note that in many instances where a suitable translation equivalent does exist, the compilers nevertheless give a number of surrogate equivalents in addition as in the articles of misdirect, mistress and mitigate in (10).

For the opposite side of $E I D$, consider extracts from the stretch -ngcuba to -ngeke in figure 8.

\begin{tabular}{|c|c|}
\hline $\begin{array}{l}\text {-ngcuba (ingcuba, } 2.9 .9 \text {, izingcuba) } \mathrm{n} \text {. } \\
\text { 1. Meat of an animal that has died, not been } \\
\text { slaughtered. } \\
\text { 2. Lean meat. } \\
\text { 3. Worthless person. } \\
\text {-ngcubangcono rel. [< ingcuba+-ngcono, lit. } \\
\text { improved dead meat.] } \\
\text { Slightly improved, on the mend. Kufiké yena } \\
\text { umhlangano waba ngcubangcono (When he arrived } \\
\text { the tone of the meeting improved). } \\
\text {-ngcubula (ingcubula, 6.6.3-8.9, izingcubula) n. } \\
\text { Fibre girdle. [cf. umkhwindi.] } \\
\text {-ngcugcu (ingcugcu, 2.6.9, izingcugcu) n. } \\
\text { Vessel narrowing at its mouth. }\end{array}$ & 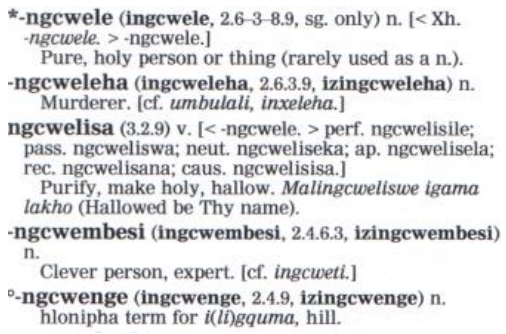 \\
\hline & \\
\hline $\begin{array}{l}\text {-ngcwecwe (imgcwecwe, 2.6.3, ongcwecwe) n. } \\
\text { [< cwecwe.] } \\
\text { 1. Thin stone or iron sheet; slate. } \\
\text { 2. [mod.] Sheet of corrugated iron or roofing } \\
\text { material. } \\
\text { ngcweka (6.3) v. [> perf. ngcwekile; pass. ngcwekwa; } \\
\text { ap. ngcwekela; caus. ngcwekisa; umngcweko.] } \\
\text { Fence, fight with sticks. } \\
\text {-ngcweko (umngcweko, } 3.2 .9 .9, \text { sg. only) n. } \\
\text { [< ngcweka.] } \\
\text { A fencing with sticks, ukudlala umngcweko (to play } \\
\text { at fencing). } \\
\text {-ngcwele rel; [< ingcwele. > ngcwelisa.] } \\
\text { Pure, holy. UMoya oNgcwele (Holy Spirit); amanzi } \\
\text { angcwele (holy water); abangcwele (holy ones). }\end{array}$ & $\begin{array}{l}\text {-ngebeza (amangebeza, } 6.6 .6 .3-8.9 \text {, pl. only) } \mathrm{n} \text {. } \\
\text { 1. Pleasant woodland glade with rocks and trees. } \\
\text { 2. Dancing arena. } \\
\text { 3. Al-fresco feast. ukudla amangebeza (to feast in } \\
\text { the open). } \\
\text {-ngebezane (ingebezane, } 2.4 .6 .8-3-8.3 \text {, izingebezane) } \\
\text { n. } \\
\text { 1. Morsel. } \\
\text { 2. Sickness which weakens the neck muscles, } \\
\text { causing the head to flop about. } \\
\text { ngedwa (6-3.9) pron. quant. 1st pers. sg. [<-dwa.] } \\
\text { I alone, only me. mina ngedwa (I alone). Bengihlezi } \\
\text { ngedwa (I was sitting by myself). } \\
\text {-ngeke defic. v. (foll. by the subjunct. mood). }\end{array}$ \\
\hline
\end{tabular}

Figure 8: Extracts from the stretch -ngcuba to -ngeke in EID 
This page is part of the alphabetical stretch $\mathrm{N}$ dealing with the alphabetical range -ngcuba--ngeke. Forty-two lemmas are presented on this page. For 24 lemmas isiZulu translation equivalents are offered of which 15 lemmas were treated using only translation equivalents. For 27 lemmas surrogate equivalents were given of which 18 lemmas were treated using only surrogate equivalents. Nine lemmas were treated using both translation equivalents and surrogate equivalents. What is important to note for the isiZulu-English side of the dictionary is the huge number of lemmas for which surrogate equivalents were used, i.e. 27 out of $42=64,3 \%$, compared to translation equivalents 24 out of $42=$ $57.1 \%$ - thus more lemmas treated with surrogate equivalents than translation equivalents. Consider table 3 and figure 9.

Table 3: The use of translation equivalents and surrogate equivalents in the isiZulu-English side of EID

\begin{tabular}{|l|c|c|}
\hline \multicolumn{1}{|c|}{ IsiZulu-English } & Counts & \% \\
\hline Lemmas treated with translation equivalents & 24 & 57,1 \\
\hline Lemmas treated with surrogate equivalents & 27 & 64,3 \\
\hline Lemmas treated with translation equivalents only & 15 & 35,7 \\
\hline Lemmas treated with surrogate equivalents only & 18 & 42,9 \\
\hline $\begin{array}{l}\text { Lemmas treated with both translation equivalents and } \\
\text { surrogate equivalents }\end{array}$ & 9 & 21,4 \\
\hline
\end{tabular}

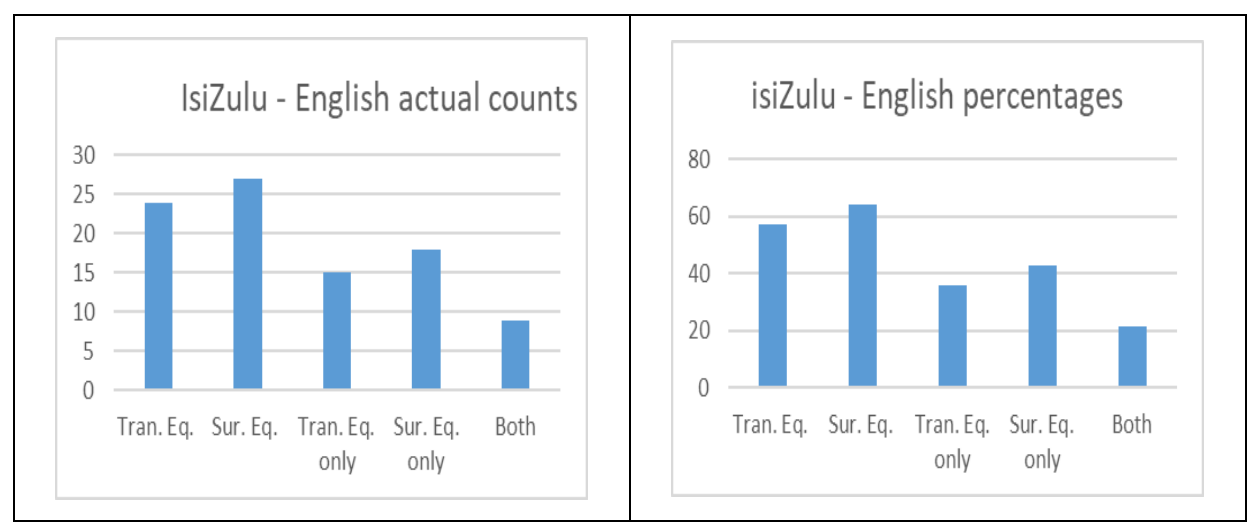

Figure 9: Translation equivalents and surrogate equivalents in -ngcuba to -ngeke in EID 
A total number of 78 equivalents were offered for the 42 lemmas treated of which 43 , i.e. $55,1 \%$ were surrogate equivalents and 35 , i.e. $44.9 \%$ were translation equivalents. Consider (11) to (13) as examples of treatment.

(11)

Translation equivalents only

-ngcwabi (umngcwabi, 2.6.6-3-8.9, abangcwabi) n.

[< ngcwaba.]

Undertaker.

-ngcumaza (3.2.9) v.

hlonipha term for dumaza, disgrace, [cf. ${ }^{\circ}$ wangaza.]

-ngcweleha (ingcweleha, 2.6.3.9, izingcweleha) $\mathrm{n}$.

Murderer, [cf. umbulali, inxeleha.]

(12)

Surrogate equivalents only

-ngcugcu (ingcugcu, 2.6.9, izingcugcu) $\mathrm{n}$.

Vessel narrowing at its mouth.

-ngcwayo (ingcwayo, 2.9.9, izingcwayo) $\mathrm{n}$.

Garment worn by women to cover the breasts and

abdomen when first married, [cf. ingcayi.]

-nge (umunge, 2.6.S-3, iminge) $\mathrm{n}$. [< nge.]

1. Hole in the bottom of a sour-milk calabash to let out the whey.

2. (sg. only) Qualms of fear; sudden flash of fear.

(13)

Both translation and surrogate equivalents

ngcwaba (6-3.9) v. [> perf. ngcwabile; pass, ngcwatshwa;

neut. ngcwabeka; ap. ngcwabela; rec. ngcwabana; caus.

ngcwabisa; int. ngcwabisisa;.umngcwabo; i(li)ngcwaba;

umngcwabi.]

1. Bury, ukungcwaba isidumbu (to bury a corpse).

2. Forget, bury in oblivion.

3. hlonipha term for gcwala, be full.

ngcweka (6.3) v. [> perf. ngcwekile; pass, ngcwekwa; ap. ngcwekela; caus. ngcwekisa; umngcweko.]

Fence, fight with sticks.

ngcwelisa (3.2.9) v. [<-ngcwele. > perf. ngcwelisile; pass, ngcweliswa; neut. ngcweliseka; ap. ngcwelisela; rec. ngcwelisana; caus. ngcwelisisa.]

Purify, make holy, hallow. Malingcweliswe igama lakho (Hallowed be Thy name). 


\section{Treatment strategies for zero equivalents in isiZulu}

Typical strategies utilised include adjective and passive constructions, adverbs, relative, possessive and negation strategies, etc. as in examples (14) to (19).

adjective

isenzo esibi 'a bad deed' (isenzo 'deed' + esibi 'bad') (noun + adjective)

(15)

passive

shiywa yisitimela 'missed a train' (shiywa 'be left behind' + yisitimela 'by the train') (verbstem + passive + copulative formative + noun)

(16)

adverbs

ukuziphatha kabi 'misbehave' (ukuziphatha 'to handle yourself' + kabi 'badly') (verb + adverb)

relative

faka ikheli elingeyilo 'misdirect' (faka 'put in' + ikheli 'address, location' elingeyilo + 'which is incorrect' (verb + noun + relative)

possessive

ukunxapha komshini wesibhamu 'misfire' (ukunxapha 'vexation' + komshini 'of the machine' + wesibhamu 'of a rifle'

(19)

negation

humusha ngokungaqondile 'misinterpret' (humusha 'mislead' + ngokungaqondile 'with not to understand) (verb + negative verb)

Comparison between the isiZulu to English alphabetical stretch -ngcuba to ngeke and the English to isiZulu stretch misdealings to mitigate in EID in table 4 and figure 10 indicate that the use of translation equivalents only is only $3.5 \%$ more in the English to isiZulu side than in the isiZulu to English side and 11\% more in the English to isiZulu side for cases where both translation equivalents and surrogate equivalents were used. However, instances where the compilers had surrogate equivalents as the only option for treatment were much more frequent, $14.5 \%$ more in the isiZulu to English side than in the English to isiZulu side of the dictionary. 
Table 4: The use of translation equivalents and surrogate equivalents in the isiZulu-English side compared to the isiZulu-English side

\begin{tabular}{|l|c|l|l|c|}
\hline \multicolumn{1}{|c|}{ IsiZulu to English } & $\%$ & \multicolumn{1}{|c|}{ English to isiZulu } & $\%$ \\
\hline Translation equivalents only & 35,7 & & Translation equivalents only & 39,2 \\
\hline Surrogate equivalents only & 42,9 & & Surrogate equivalents only & 28,4 \\
\hline $\begin{array}{l}\text { Both Translation equivalents and sur- } \\
\text { rogate equivalents }\end{array}$ & 21,4 & $\begin{array}{l}\text { Both Translation equivalents and } \\
\text { surrogate equivalents }\end{array}$ & 32,4 \\
\hline
\end{tabular}

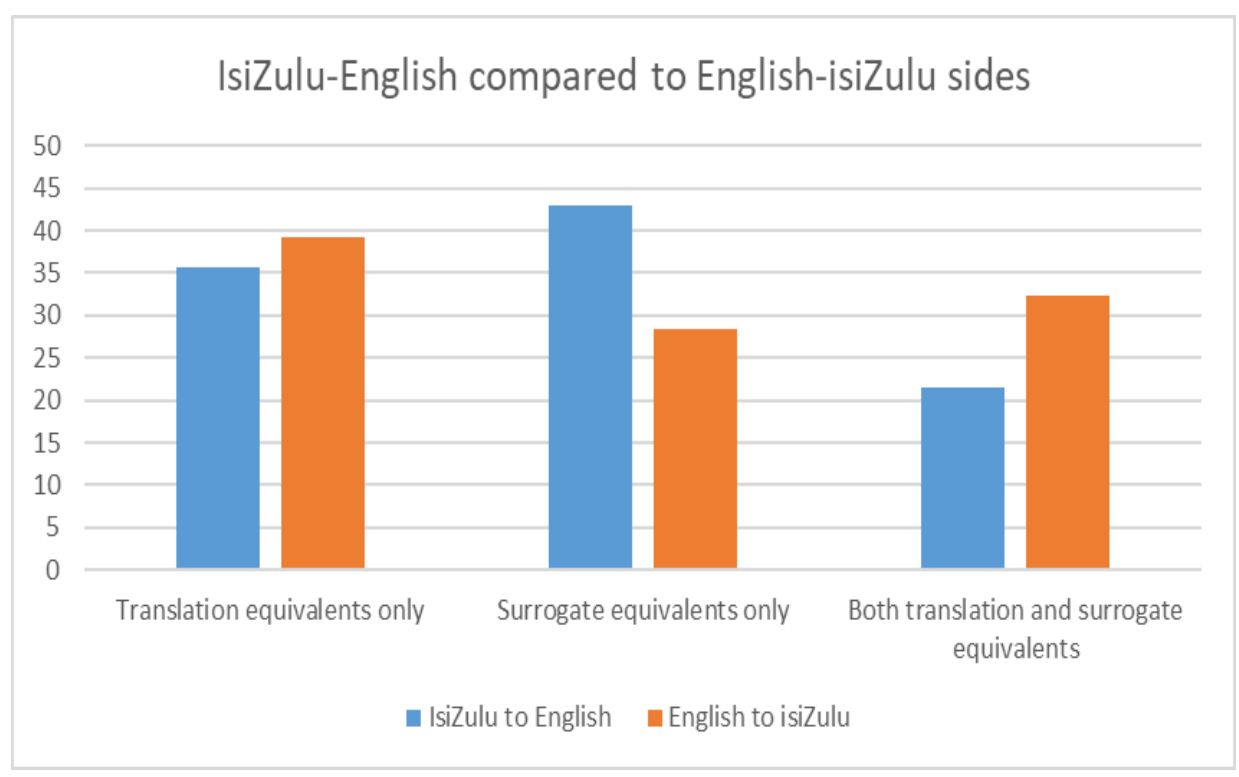

Figure 10: Comparison between isiZulu to English and English to isiZulu

A total number of 101 surrogate equivalents were used in the treatment of lemmas in the two randomly selected pages from the isiZulu to English and the English to isiZulu sides of the dictionary. Extrapolation for the entire dictionary gives a total of 63,000 instances of the use of surrogate equivalents in EID. A total number of 171 translation equivalents were used in these two pages. Extrapolation for the entire dictionary gives a total of 107,000. It is clear that the occurrence of zero equivalence is not rare in English-isiZulu dictionaries.

\section{Conclusion}

A fundamental task of the lexicographer is to act as the mediator between the 
language(s) treated in the dictionary and the target user. In modern lexicography users require a user friendly reference work in which they, in terms of Haas (1962) could find the word preferably in the first place they are looking and in terms of Laufer (1992) enabled by the lookup to "know the word". In respect of lexical gaps the lexicographer should utilise all treatment options available such as loan words, paraphrase of meaning and pictorial illustrations to guide the users to understand the meaning of a word. In this article it has been indicated that lexical gaps are very frequent in the language pair isiZulu/English and subsequently poses a big challenge to the lexicographer to treat them in a satisfactory way in English-isiZulu / isiZulu-English bilingual dictionaries. Lexical gaps in isiZulu (English as source language and isiZulu as target language) are less frequent than lexical gaps in English (isiZulu as source language and English as target language). The research results indicate that EID did well in the treatment of the many lexical gaps in both directions of the dictionary. IsiZulu is rich in cultural terms for which there are no English equivalents and the compilers put much effort into finding ways to convey the meaning of such words. Likewise, for the lexical gaps in isiZulu, users are wellprovided with surrogate equivalents.

\section{Acknowledgements}

This research is supported by the South African Centre for Digital Language Resources (SADiLaR). Findings and conclusions are those of the authors.

\section{Bibliography}

\section{Dictionaries}

(CZD) Dent, G.R. (Compiler) and C.L.S. Nyembezi (Ed.). 1961. Compact Zulu Dictionary EnglishZulu, Zulu-English. Pietermaritzburg: Shuter \& Shooter.

(DL) Hartmann, R.R.K. and G. James. 1998. Dictionary of Lexicography. London/New York: Routledge.

(EID) Doke, C.M., D.M. Malcolm, J.M.A. Sikakana and B.W. Vilakazi. 2016. English-IsiZulu, IsiZuluEnglish Dictionary. Johannesburg: Wits University Press and South African Heritage Publishers.

(EXD) Fischer, A., E. Weiss, S. Tshabe and E. Mdala. 1993. English-Xhosa Dictionary. Cape Town: OUP Southern Africa.

(GDX1) Tshabe, S.L. (Editor-in-Chief). 2006. The Greater Dictionary of isiXhosa. Volume 1: A to J. Alice: IsiXhosa National Lexicography Unit, University of Fort Hare.

(GDX2) Mini, B.M. (Editor-in-Chief). 2003. The Greater Dictionary of isiXhosa. Volume 2: K to P. Alice: IsiXhosa National Lexicography Unit, University of Fort Hare.

(GDX3) Pahl, H.W. (Editor-in-Chief). 1989. The Greater Dictionary of Xhosa Volume 3: Q to Z. Alice: University of Fort Hare. 
(MD) Macmillan Dictionary. Available online at https://www.macmillandictionary.com. [Accessed on 20 August 2020]

(OZD) De Schryver, G.-M. (Ed.). 2010. Oxford Bilingual School Dictionary: Zulu and English. Cape Town: OUP Southern Africa.

(SZD) Dent, G.R. and C.L.S. Nyembezi. 1988. Scholar's Zulu Dictionary. Second edition. Pietermaritzburg: Shuter \& Shooter.

\section{Other}

Adamska-Sałaciak, Arleta. 2006. Meaning and the Bilingual Dictionary. The Case of English and Polish. Frankfurt am Main: Peter Lang.

Dagut, M. 1981. Semantic Voids as a Problem in the Translation Process. Poetics Today 2(4). 61-71.

Gouws, R.H. and D.J. Prinsloo. 2005. Principles and Practice of South African Lexicography. Stellenbosch: SUN PReSS.

Gouws, R.H. and D.J. Prinsloo. 2008. What to Say about "mañana", "totems" and "dragons" in a Bilingual Dictionary? The Case of Surrogate Equivalence. Bernal, E. and J. DeCesaris (Eds.). 2008. Proceedings of the XIII EURALEX International Congress, Barcelona, 15-19 July 2008: 869-877. Barcelona: Universitat Pompeu Fabra, Institut Universitari de Lingüística Aplicada.

Gouws, R.H. and D.J. Prinsloo. 2010. Surrogaatekwivalensie in tweetalige woordeboeke met spesifieke verwysing na zero-ekwivalensie in Afrikataalwoordeboeke. [Surrogate Equivalence in Bilingual Dictionaries with Special Reference to Zero Equivalence in Dictionaries for African Languages]. Tydskrif vir Geesteswetenskappe 50(4): 502-519.

Haas, M.R. 1962. What Belongs in the Bilingual Dictionary? Householder, F.W. and S. Saporta (Eds.). 1962. Problems in Lexicography: 45-50. Bloomington: Indiana University.

Laufer, B. 1992. Corpus-based versus Lexicographer Examples in Comprehension and Production of New Words. Tommola, H. et al (Eds.). 1992. EURALEX '92 Proceedings I-II: Papers Submitted to the 5th EURALEX International Congress on Lexicography in Tampere, Finland: 71-76. Tampere: University of Tampere. 